\title{
Kartu Uno untuk Meningkatkan Kemampuan Pemahaman Konsep Matematis Siswa SMP
}

\author{
Fidi Dwi Anita ${ }^{1}$, Pujia Siti Balkist ${ }^{2}$, Novi Andri Nurcahyono ${ }^{3}$ \\ ${ }^{123}$ Program Studi Pendidikan Matematika, Fakultas Keguruan dan Ilmu Pendidikan, Universitas Muhammadiyah Sukabumi, \\ Jl. R. Syamsudin, S.H. No. 50 Sukabumi \\ dwianitafidi@gmail.com
}

\begin{abstract}
This study aims to develop Uno Cards as a medium of learning to improve the ability to understand mathematical concepts of junior high school students. The type of research used is development research with the ADDIE model (analysis, design, development, implementation, evaluation). The research subjects were 13 students of class VIII MTs Baitussalam. The instruments used in this research are material and media expert validation sheets to determine product validity, teacher and student response questionnaires are used to determine the practicality of the product and test the ability to understand mathematical concepts to determine product effectiveness test results. The results of this study indicate: (1) Material and media expert validation states that the Uno card learning media is included in the valid criteria it is feasible to use. (2) The response of teachers and students to the uno card learning media is very good and includes very practical criteria. (3) Based on the N-Gain analysis, the N-Gain value is 79.21, it shows that there is an increase in the ability to understand mathematical concepts of students.
\end{abstract}

Keywords: Mathematical Concept Understanding Ability, ADDIE, Learning Media, Uno Card

\begin{abstract}
Abstrak
Penelitian ini bertujuan untuk mengembangkan Kartu Uno sebagai media pembelajaran untuk meningkatkan kemampuan pemahaman konsep matematis siswa SMP. Jenis penelitian yang digunakan adalah penelitian pengembangan dengan model ADDIE (analysis, design, development, implementation, evaluation). Subjek penelitian adalah 13 siswa kelas VIII MTs Baitussalam.Instrumen yang digunakan dalam penelitian ini yaitu berupa lembar validasi ahli materi dan media untuk mengetahui validitas produk, angket respon guru dan siswa digunakan untuk mengetahui kepraktisan produk, serta tes kemampuan pemahaman konsep matematis untuk mengetahui hasil uji efektifitas produk. Hasil penelitian ini menunjukkan: (1) Validasi ahli materi dan media menyatakan media pembelajaran kartu uno termasuk dalam kriteria valid yang artinya layak untuk digunakan. (2) Respon guru dan siswa terhadap media pembelajaran kartu uno sangat baik dan termasuk kriteria sangat praktis. (3) Berdasarkan analasis N-Gain, diperoleh nilai N-Gain yaitu 79.21hal tersebut menunjukkan bahwa terjadinya peningkatan kemampuan pemahaman konsep matematis siswa.
\end{abstract}

Kata kunci: Kemampuan Pemahaman Konsep Matematis, ADDIE, Media Pembelajaran, Kartu Uno

Copyright (c) 2022 Fidi Dwi Anita, Pujia Siti Balkist, Novi Andri Nurcahyono $\triangle$ Corresponding author: Fidi Dwi Anita

Email Address: dwianitafidi@gmail.com (Kp Pondok Leungsir Cicantayan, Sukabumi)

Received 26 August 2021, Accepted 21 October 2021, Published 26 January 2022

\section{PENDAHULUAN}

Pendidikan merupakan sarana untuk mengembangkan potensi dalam diri setiap manusia. Hal ini sejalan dengan Undang-Undang No.20 Tahun 2003 menyatakan bahwa pendidikan merupakan usaha sadar dan terencana untuk mewujudkan suasana belajar dan proses pembelajaran agar siswa secara aktif mengembangkan potensi dalam dirinya. Pendidikan diharapkan dapat menjadi sarana bagi siswa untuk memperoleh ilmu pengetahuan dan menerapkannya dalam kehidupan sehari-hari.Ilmu pengetahuan yang berguna dalam kehidupan sehari-hari salah satunya yaitu matematatika.Matematika 
Kartu untuk Meningkatkan Kemampuan Pemahaman Konsep Mataematis Siswa SMP, Fidi Dwi Anita, Pujia Siti Balkist,

merupakan mata pelajaran yang diajarkan dari mulai sekolah dasar, sekolah menengah, sampai perguruan tinggi. Karena matematika sebagai salah satu bagian penting dalam upaya meningkatkan mutu pendidikan (Novitasari, 2016). Salah satu tujuan pembelajaran matematika menurut Depdiknas (2006)(Permendiknas No. 22 Tahun 2006) yaitu memahami konsep matematika, menjelaskan keterkaitan antar konsep dan mengaplikasikan konsep atau algoritma secara luwes, akurat, efisien, dan tepat dalam pemecahan masalah.

Berdasarkan hasil studi TIMSS 2015, posisi Indonesia mengenai prestasi matematika masih kurang. Indonesia berada pada peringkat ke 44 dari 49 negara dengan skor rata-rata 397, sedangkan skor rata-rata internasional yaitu 500 (Hadi \& Novaliyosi, 2019). Terdapat beberapa faktor yang menyebabkan rendahnya kemampuan pemahaman matematis siswa, antara lain siswa terbiasa mempelajari konsep dan rumus matematika dengan cara menghafal tanpa memahami maksud, isi, dan kegunaannya (Tri \& Hidayati, 2019). Sejalan dengan hasil wawancara dengan guru di salah satu SMP Kabupaten Sukabumi menyatakan bahwa kemampuan siswa dalam memahami materi berbeda-beda. Ketika siswa diberikan latihan soal yang berbeda dengan contoh yang diajarkan guru, siswa merasa kebingungan dan kesulitan. Karena siswa cenderung hanya menghafal rumus tanpa memahami konsep materi yang diajarkan. Serta pembelajaran matematika merupakan pembelajaran yang dianggap sulit dan tidak mudah untuk dipahami (Supriatna \& Nurcahyono, 2017). Hal tersebut menyebabkan kurangnya ketertarikan siswa dalam pembelajaran matematika dan menimbulkan rendahnya kemampuan pemahaman konsep matematis siswa. Oleh karena itu, perlu adanya media pembelajaran yang menyenangkan sehingga dapat menarik minat siswa untuk belajar dan membantu siswa dalam memahami materi yang diajarkan.

Media pembelajaran yang digunakan yaitu media pembelajaran berupa permaianan, karena dapat menarik minat dan semangat siswa dalam belajar, sehigga diharapkan siswa akan dengan mudah dalam memahami materi. Menurut Komariyah \& Sadiman (2013) penambahan permainan dalam pembelajaran memiliki dua aspek positif. Pertama, aspek kemenarikan. Aspek kemenarikan diperoleh dari situasi belajar yang santai sambil bermain yang diterapkan dalam proses pembelajaran. Kedua, aspek mendidik.Aspek mendidik diperoleh dari penerapan konsep yang dimiliki dengan menerapkan strategi serta kreativitas siswa dalam menyelesaikan permainan. Terdapat berbagai media pembelajaran berupa permainan yang telah dikembangkan dan digunakan, salah satunya yaitu media pembelajaran kartu uno. Menurut Rohrig (Hidayati \& Hakim, 2014) uno merupakan permainan kartu keluarga dengan peraturan yang mudah untuk dimainkan siapapun diatas usia tujuh tahun. Penggunaan media pembelajaran kartu uno sebelumnya telah dilakukan dalam penelitian yang dilakukan oleh Witantyo (2017) yaitu pengembangan media pembelajaran kartu uno akuntansi untuk meningkatkan motivasi belajar siswa, yang menunjukkan bahwa hasil posttest lebih baik dari hasil pretest dan adanya peningkatan motivasi belajar pada siswa. Selain itu, penelitian yang dilakukan Estiani dkk (2015) dalam pengembangan media permainan kartu uno untuk meningkatkan kemampuan pemahaman konsep dan karakter siswa kelas VII pada materi optik menunjukkan bahwa 
media permainan kartu uno memberikan pengaruh baik dalam meningkatkan kemampuan pemahaman konsep.

Pada penelitian ini kartu uno yang dikembangkan memuat materi aritmatika sosial dan terdapat latihan soal yang dapat melatih kemampun pemahaman konsep matematis siswa. Oleh karena itu, peneliti akan mengembangkan "Kartu Uno sebagai untuk Meningkatkan Kemampuan Pemahaman Konsep Matematis Siswa SMP” yang bertujuan menciptakan media pembelajaran yang valid, praktis, dan efektif.

\section{METODE}

Jenis penelitian yang digunakan adalah penelitian pengembangan (Research and Development).Penelitian dan pengembangan merupakan proses/metode yang digunakan untuk menghasilkan produk tertentu, dan menguji keefektifan dari produk tersebut (Sugiyono, 2015). Produk yang dihasilkan berupa kartu uno yang dimodifikasi dan dibuat menggunakan aplikasi photoshop. Model pengembangan yang digunakan adalah model pengembangan ADDIE yang terdiri dari analysis, design, development, implementation, evaluation. Model pengembangan ini pilih karena sesuai dengan pendapat Sidarta \& Yuanita (2019) yang mengungkapkan karakteristik model pengembangan ADDIE sangat cocok digunakan untuk mengembangkan media pembelajaran berbentuk permainan dan media cetak.Berikut tahapan dari model pengembangan ADDIE dapat dilihat pada tabel 1 .

Tabel 1. Pengembangan Model ADDIE

\begin{tabular}{|c|l|}
\hline $\begin{array}{c}\text { Tahapan } \\
\text { Pengembagan }\end{array}$ & \multicolumn{1}{|c|}{ Kegiatan } \\
\hline Analysis & $\begin{array}{l}\text { Analisis permasalahan dan solusi yang sesuai dengan kebutuhan } \\
\text { siswa. }\end{array}$ \\
\hline Design & $\begin{array}{l}\text { Perancangan desain media pembelajaran kartu uno, penyusunan } \\
\text { materi dan soal serta penyusunan aturan main, pembuatan kartu } \\
\text { dengan menggunakan aplikasi photoshop. }\end{array}$ \\
\hline Development & $\begin{array}{l}\text { Mengembangkan media pembelajarran kartu uno yang telah } \\
\text { dirancang (Validasi ahli materi dan media) }\end{array}$ \\
\hline Implementation & Mengimplementasikan media pembelajaran kartu uno. \\
\hline Evaluation & $\begin{array}{l}\text { Menilai kualitas media dan proses pembelajaran sebelum dan } \\
\text { sesudah menggunakan media. }\end{array}$ \\
\hline
\end{tabular}

Teknik analisis data yang digunakan sesuai dengan jenis data yaitu kualitatif dan kuantitatif. Data kualitatif diperoleh dari tanggapan dan saran ahli materi, ahli media, dan guru serta siswa mengenai produk yang dikembangkan. Data kuantitatif diperoleh berdasarkan hasil validasi ahli materi dan media, hasil angket respon guru dan siswa, dan hasil tes siswa. Skala pengukuran yang digunakan pada lembar validasi ahli dan angket respon guru serta siswa yaitu dengan menggunakan skala likert. Skala likert digunakan untuk mengukur sikap, pendapat, dan persepsi seseorang atau sekelompok orang tentang fenomena sosial, dimana fenomena sosial ini telah ditetapkan oleh peneliti 
yang selanjutnya disebut sebagai variabel penelitian (Sugiyono, 2015). Analisis kevalidan produk dapat dihitung dengan menggunakan rumus (Arikunto, 2009):

$$
\text { Hasil }=\frac{\text { Total skor yang diperoleh }}{\text { Skor Maksimum }} \times 100 \%
$$

Selanjutnya hasil data tersebut diinterpretasikan dengan kriteria kevalidan menurut Arikunto (2009)

Tabel 2. Kriteria Kevalidan Media

\begin{tabular}{|c|c|}
\hline Persentase & Kriteria Kevalidan \\
\hline$<21 \%$ & Sangat Tidak Valid \\
\hline $21 \%-40 \%$ & Tidak Valid \\
\hline $41 \%-60 \%$ & Cukup Valid \\
\hline $61 \%-80 \%$ & Valid \\
\hline $81 \%-100 \%$ & Sangat Valid \\
\hline
\end{tabular}

Suatu produk dikatakan valid jika rata-rata skor minimal dalam kriteria valid atau setara dengan mencapai 61\% - 80\% (Subekti, 2014).

Analisis kepraktisan produk dapat dihitung dengan menggunakan rumus

$$
\text { Hasil }=\frac{\text { Total skor yang diperoleh }}{\text { Skor Maksimum }} \times 100 \%
$$

Selanjutnya hasil data tersebut di interpretasikan dengan kriteria kepraktisan menurut Ridwan (Puji dkk, 2014)

Tabel 3. Kriteria Kepraktisan Media

\begin{tabular}{|l|l|}
\hline Nilai Angket & Kriteria Kepraktisan \\
\hline $81 \%-100 \%$ & Sangat Praktis \\
\hline $61 \%-80 \%$ & Praktis \\
\hline $41 \%-60 \%$ & Cukup Praktis \\
\hline $21 \%-40 \%$ & Tidak Praktis \\
\hline $0 \%-21 \%$ & Sangat Tidak Praktis \\
\hline
\end{tabular}

Suatu produk dikatakan praktis jika rata-rata skor dari guru dan siswa mencapai $61 \%$ - 80\% atau dalam kriteria praktis (Subekti, 2014). Efektivitas produk yang dikembangkan diketahui dengan adanya peningkatan dari kemampuan pemahaman konsep matematis siswa. Desain yang digunakan yaitu one-group pretest-posttest design. Nilai pretest dan posttest kemudian dianalisis dengan menggunakan analisis N-Gain berdasarkan rumus menurut Archambault (Situmorang dkk, 2015)

$$
\mathrm{N}-\text { Gain }=\frac{\text { Skor } \text { Postest }- \text { Skor } \text { Pretest }}{\text { Skor Maks-Skor Pretest }} \times 100
$$

Hasil skor Gain Ternormalisasi dibagi dalam tiga kategori, yaitu:

Tabel 4. Hasil Skor Gain Ternormalisasi

\begin{tabular}{|l|l|}
\hline Skor & Kriteria \\
\hline $\mathrm{N}-$ Gain $>70$ & Tinggi \\
\hline $30 \leq \mathrm{N}-$ Gain $\leq 70$ & Sedang \\
\hline $\mathrm{N}-$ Gain $<30$ & Rendah \\
\hline
\end{tabular}




\section{HASIL DAN DISKUSI}

Analysis

Pada tahap ini, analisis yang dilakukan berupa analisis kebutuhan siswa dan analisis kompetensi. Berdasarkan hasil wawancara dengan guru matematika terkait permasalahan pembelajaran diperoleh hasil bahwa siswa membutuhkanmedia pembelajaran yang dapat membantu siswa untuk meningkatkan kemampuan pemahaman konsep, serta media pembelajaran yang menyenangkan dan melibatkan siswa secara langsung. Permasalahan lain, siswa belum memahami materi yang menjelaskan mengenai arti dari pajak, arti bunga, bagaimana menentukan neto dan besarnya bunga tabungan atau pinjaman. Hal tersebut menjadi alasan peneliti untuk memilih materi aritmatika sosial dalam pembuatan media.

\section{Design}

Tahap ini diawali dengan perencanaan desain media pembelajaran, penyusunan materi dan latihan soal serta aturan permaianan, dan pembuatan produk. Berikut penjelasannya:

\section{Perencanaan Desain Media Pembelajaran}

Pada media kartu uno yang dikembangkan oleh peneliti terdapat komponen kartu yang dimodifikasi sehingga memiliki fungsi yang berbeda dengan tujuan agar adanya kesesuaian media pembelajaran yang dikembangkan. Pada permaian kartu uno terdapat deal card yang berfungsi sebagai kartu yang berisi angka dan warna, jika kartu ini dimainkan maka pemain selanjutnya harus mempunyai kartu dengan warna atau angka yang sama. Namun, pada media kartu uno yang dikembangkan deal card dimodifikasi menjadi kartu materi yang berfungsi sebagai kartu yang berisi materi dari sub materi yang sudah dikelompokkan dengan warna yang sama.

\section{Penyusunan Materi, Latihan Soal, dan Aturan Permainan}

Materi yang digunakan pada media pembelajaran ini adalah materi aritmatika sosial SMP. Materi yang disajikan antara lain: 1) keuntungan dan kerugian; 2) pajak, bunga tunggal, dan diskon; 3) bruto, neto, dan tara. Selain itu, media ini terdapat latihan soal dan kunci jawaban agar siswa memahami materi yang disajikan.Soal yang diberikan sesuai dengan materi dan indikator kemampuan pemahaman konsep matematis siswa. Adapun indikator yang digunakan yaitu: 1) menyatakan ulang sebuah konsep; 2) mengklasifikasikan objek menurut sifat tertentu sesuai dengan konsepnya; 3) menggunakan dan memanfaatkan serta memilih prosedur atau operasi tertentu; 4) mengaplikasikan konsep atau algoritma pada pemecahan masalah. Aturan permaian media pembelajaran kartu uno adalah menyesuaikan isi kartu materi (kartu yang berisi sub materi) pada kartusaem (kartu yang berisi tema materi).

\section{Pembuatan Produk}

Pembuatan media pembelajaran kartu uno yaitu dengan menggunakan aplikasi photoshop. Setiap kartu pada media pembelajaran didesain dengan gambar dan warna berbeda yang disesuaikan dengan materi yang akan disajikan dalam media pembelajaran kartu uno. 
Kartu untuk Meningkatkan Kemampuan Pemahaman Konsep Mataematis Siswa SMP, Fidi Dwi Anita, Pujia Siti Balkist, Novi Andri Nurcahyono

\section{Development}

\section{Validitas Produk}

Media pembelajaran yang sudah dibuat kemudian dilakukan uji validitas atau dilakukan proses validasi media pembelajaran yang bertujuan untuk memperoleh penilaian serta saran-saran perbaikan dari validator. Saran perbaikan tersebut dijadikan sebagai acuan dan bahan pertimbangan untuk memperbaiki produk yang dikembangkan oleh peneliti. Berikut data kualitatif dan data kuantitatif dari hasil validasi oleh para ahli:

Tabel 5. Data Kualitatif Hasil Validasi Ahli Media dan Ahli Materi

\begin{tabular}{|c|c|c|}
\hline No & Validasi Ahli & Saran Perbaikan \\
\hline \multirow{5}{*}{1} & \multirow{5}{*}{ Media } & $\begin{array}{l}\text { Penggunaan font tulisan sebaiknya diganti dengan font yang } \\
\text { sedikit informal }\end{array}$ \\
\hline & & $\begin{array}{l}\text { Font yang digunakan kurang sesuai sehingga mempengaruhi } \\
\text { keterbacaan teks. }\end{array}$ \\
\hline & & Pemilihan warna teks dibuat kontras agar lebih terbaca. \\
\hline & & $\begin{array}{l}\text { Tambahkan kesan menonjol di ilustrasi dan title pada kartu } \\
\text { materi. }\end{array}$ \\
\hline & & Letak font dan ilustrasi disesuaikan dengan banyaknya space. \\
\hline \multirow{3}{*}{2} & \multirow{3}{*}{ Materi } & Tambahkan jumlah soal. \\
\hline & & Sesuaikan soal dengan indikator pemahaman konsep. \\
\hline & & Penggunaan bahasa pada soal. \\
\hline
\end{tabular}

Tabel 6. Data Kuantitatif Hasil Validasi Materi

\begin{tabular}{|c|c|c|c|c|}
\hline No & Validator & Aspek & Rata-rata & Kriteria \\
\hline \multirow{2}{*}{1} & \multirow{2}{*}{ Ahli Materi 1 } & Kualitas Isi dan Tujuan & $62 \%$ & Valid \\
\cline { 3 - 5 } & & Kualitas Instruksional & $53 \%$ & Cukup Valid \\
\hline \multirow{2}{*}{2} & \multirow{2}{*}{ Ahli Materi 2 } & Kualitas Isi dan Tujuan & $80 \%$ & Valid \\
\cline { 3 - 5 } & Kualitas Instruksional & $80 \%$ & Valid \\
\hline \multirow{2}{*}{3} & \multirow{2}{*}{ Ahli Materi 3 } & Kualitas Isi dan Tujuan & $96 \%$ & Sangat Valid \\
\cline { 3 - 4 } & \multicolumn{2}{|r}{ Kualitas Instruksional } & $100 \%$ & Sangat Valid \\
\hline \multicolumn{2}{|r}{ Rata-rata keseluruhan } & $79 \%$ & Valid \\
\hline
\end{tabular}

Tabel 7. Data Kuantitatif Hasil Validasi Ahli Media

\begin{tabular}{|c|c|c|c|c|}
\hline No & Validator & Aspek & Rata-rata & Kriteria \\
\hline 1 & Ahli Media 1 & Kualitas Teknis & $84 \%$ & Sangat Valid \\
\hline 2 & Ahli Media 2 & Kualitas Teknis & $78 \%$ & Valid \\
\hline 3 & Ahli Media 3 & Kualitas Teknis & $69 \%$ & Valid \\
\hline \multicolumn{3}{|c|}{ Rata-rata keseluruhan } & $77 \%$ & Valid \\
\hline
\end{tabular}

Berdasarkan hasil dari kedua validasi tersebut dapat diketahui jika pada validasi materi mendapatkan kriteria valid dan pada validasi media mendapatkan kriteria valid, maka dapat disimpulkan bahwa media pembelajaran valid dan layak untuk digunakan dengan rata-rata sebesar $79 \%$ pada rentan $61 \%-80 \%$ dengan kriteria valid. Berikut adalah tampilan produk yang telah melalui tahap validasi dan revisi: 

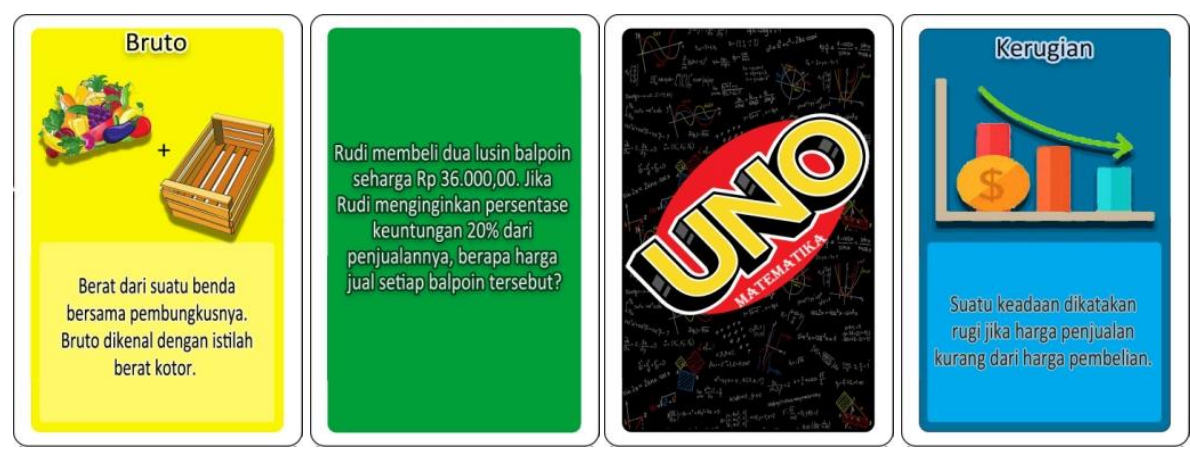

Gambar 1. Tampilan Media Pembelajaran Kartu Uno Setelah Validasi Ahli dan Revisi

\section{Implementation}

Tahap ini merupakan tahapan melaksanakan penelitian yang diawali dengan mempersiapkan media pembelajaran, tempat dan alat penelitian serta siswa untuk proses pembelajaran. Tahapan ini dilakukan untuk mendapatkan penilaian kepraktisan dan keefektifan media pembelajaran yang dikembngkan.Cara bermain kartu uno yang dikembangkan sama dengan kartu uno pada umumnya. Awalnya pemain dibagikan empat kartu secara acak. Pemain harus mengetahui materi apa yang dibahas/sesuai dengan tema pada kartu saem. Jika pemain tidak mempunyai kartu yang dimaksud, maka pemain harus mengambil satu kartu dari kartu tarikan. Misalkan, apabila tema yang dibahas yaitu mengenai "keuntungan dan kerugian", maka pemain harus memainkan kartu tentang pengertian keuntungan, persentase keuntungan, pengertian kerugian, serta persentase kerugian.

\section{Hasil Penilaian Respon Guru dan Siswa terhadap Penggunaan Media Pembelajaran}

Penilaian ini diperoleh untuk mengetahui kepraktisan media pembelajaran yang peneliti kembangkan.Angket ini diberikan kepada guru dan 13 siswa yang telah menggunakan media pembelajaran. Berikut hasil penilaian respon guru dan siswa:

Tabel 8. Hasil Penilaian Respon Guru terhadap Media

\begin{tabular}{|c|c|c|c|c|}
\hline No & Aspek & $\begin{array}{c}\text { Jumlah } \\
\text { Skor }\end{array}$ & Rata-rata & Kriteria \\
\hline 1 & Tujuan dan Isi & 8 & $80 \%$ & Praktis \\
\hline 2 & Kemudahan & 12 & $80 \%$ & Praktis \\
\hline 3 & Minat Siswa & 12 & $80 \%$ & Praktis \\
\hline 4 & Keterampilan Siswa & 4 & $80 \%$ & Praktis \\
\hline 5 & Waktu & 4 & $80 \%$ & Praktis \\
\hline 6 & Keterbantuan Guru & 8 & $80 \%$ & Praktis \\
\hline \multicolumn{3}{|c|}{ Rata-rata keseluruhan } & $80 \%$ & Praktis \\
\hline
\end{tabular}

Tabel 9. Hasil Penilaian Respon Siswa terhadap Media

\begin{tabular}{|c|l|c|c|c|}
\hline No & \multicolumn{1}{|c|}{ Aspek } & $\begin{array}{c}\text { Jumlah } \\
\text { Skor }\end{array}$ & Rata-rata & Kriteria \\
\hline 1 & Media & 317 & $98 \%$ & Sangat Praktis \\
\hline 2 & Materi & 300 & $92 \%$ & Sangat Praktis \\
\hline 3 & Pembelajaran & 123 & $95 \%$ & Sangat Praktis \\
\hline \multicolumn{2}{|c|}{ Rata-rata keseluruhan } & $95 \%$ & Sangat Praktis \\
\hline
\end{tabular}


Kartu untuk Meningkatkan Kemampuan Pemahaman Konsep Mataematis Siswa SMP, Fidi Dwi Anita, Pujia Siti Balkist,

Berdasarkan hasil penilaian, respon guru mendapatkan kriteria praktis dan respon siswa mendapatkan kriteria sangat praktis. Maka dapat disimpulkan bahwa media pembelajaran yang dikembangkan oleh peneliti sangat praktis untuk digunakan, dengan rata-rata sebesar 94\% pada rentan $61 \%-80 \%$ dengan kriteria sangat praktis.

\section{Efektifitas Produk}

Efektifitas produk ini diketahui dengan melakukan uji efektifitas.Uji efektifitas dilakukan dengan menggunakan desain one-group pretest-posttest design.Untuk mengukur peningkatan kemampuan pemahman konsep matematis siswa dalam hal ini dengan menggunakan analisis $\mathrm{N}$ Gain.Berdasarkan hasil tes yang dilakukan pada saat uji coba, diperoleh rata-rata nilai pretest siswa yaitu 69.23 dan rata-rata nilai posttest siswa yaitu 94.23. Adapun hasil perhitungan yang diperoleh dari hasil jawaban pretest dan posttest siswa dapat dilihat pada tabel berikut:

Tabel 10. Hasil Perhitungan Nilai N-Gain

\begin{tabular}{|c|c|c|}
\hline $\begin{array}{c}\text { Jumlah Nilai } \\
\text { N-Gain }\end{array}$ & $\begin{array}{c}\text { Rata-rata Nilai } \\
\text { N-Gain }\end{array}$ & Kriteria \\
\hline 1029.761905 & 79.21245421 & Tinggi \\
\hline
\end{tabular}

Berdasarkan hasil perhitungan N-Gain di atas, diperoleh rata-rata N-Gain yaitu 79.21 dimana nilai tersebut memenuhi kriteria "Tinggi". Maka dapat disimpulkan bahwa kemampuan pemahaman konsep matematis siswa mengalami peningkatan setelah menggunakan media pembelajaran kartu uno sehingga media pembelajaran yang dikembangkan oleh peneliti efektif untuk digunakan.

\section{Evaluation}

Tahapan ini yaitu untuk mengetahui hasil akhir penilaian dan perbaikan pada media pembelajaran kartu uno yang dikembangkan.

\section{KESIMPULAN}

Berdasarkan hasil dan pembahasan maka dapat disimpulkan yaitu: 1) Validasi ahli materi dan media menyatakan media pembelajaran kartu uno termasuk dalam kriteria valid dengan rata-rata $79 \%$ yang artinya layak untuk digunakan, 2) Respon guru dan siswa terhadap media pembelajaran kartu uno sangat baik dan termasuk kriteria sangat praktis dengan rata-rata 94\% dan layak digunakan, 3) Berdasarkan analasis N-Gain, diperoleh nilai N-Gain yaitu 79.21 hal tersebut menunjukkan bahwa terjadinya peningkatan kemampuan pemahaman konsep matematis siswa yang mana media kartu uno efektif untuk digunakan. Sehingga dari hasil yang diperoleh yaitu berupa kevalidan, kepraktisan, dan keefektifan yang menunjukkan bahwa media kartu uno yang dikembangkan layak untuk digunakan dalam proses pembelajaran. 


\section{UCAPAN TERIMA KASIH}

Peneliti mengucapkan terima kasih kepada Allah SWT karena berkat karunia dan pertolonganNya, peneliti dapat menyelesaikan penelitian ini.Terima kasih kepada kedua orang tua peneliti yang selalu mendukung dan memberi motivasi serta doa. Selain itu, terima kasih juga kepada keluarga dan sahabat-sahabat yang membantu serta memberikan semangat kepada peneliti.Terima kasih juga peneliti sampaikan kepada para validator yang telah memberikan saran dan kritik yang membangun kepada peneliti, dan terima kasih kepada pihak sekolah yang memberikan izin peneliti untuk melakukan penelitian di sekolah tersebut.

\section{REFERENSI}

Arikunto. (2009). Dasar-dasar Evaluasi Pendidikan. Jakarta: Bumi Aksara.

Depdiknas. (2006). Permendiknas No. 22 Tahun 2006 Tentang Standar Isi. Jakarta: Depdiknas.

Estiani dkk. (2015). Pengembangan Media Pembelajaran Kartu Uno untuk Meningkatkan Pemahaman Konsep dan Karakter Siswa Kelas VII Tema Optik. Unnes Science Education Journal, 4(1).

Hadi, S., \& Novaliyosi. (2019). TIMSS Indonesia (Trends In Internasional Mathematics Ans Science Studi). Prosiding Seminar Nasional \& Call For Papers, Tasikmalaya.

Hidayati, N., \& Hakim, L. (2014). Pengembangan Permainan Kartu Uno Sebagai Alat Evaluasi Pembelajaran Akuntansi Pokok Bahasan Hutang Jangka Panjang. Jurnal Pendidikan Akuntansi, 2(2).

Komariyah, \& Sadiman, B. (2013). Penggunaan Media Kartu Bilangan Untuk Meningkatkan Hasil Belajar Penjumlahan dan Pengurangan Bilangan Pecahan Pada Mata Pelajaran Matematika Siswa Kelas V SD Al-Amin Surabaya. Jurnal Penelitian Pendidikan Guru Sekolah Dasar, $1(1)$.

Novitasari, D. (2016). Pengaruh Penggunaan Multimedia Interaktif Terhadap Kemampuan Pemahaman Matematis Siswa. Jurnal Pendidikan Matematika Dan Matematika, 2(2).

Puji dkk. (2014). Pengembangan Multimedia Interaktif Untuk Pembelajaran Bentuk Molekul di SMA. Jurnal Pendidikan Kimia, 1(1).

Sidarta, K. T., \& Yuanita, T. N. H. (2019). Pengembangan Kartu Domano (Domino Matematika Trigono) Sebagai Media Pembelajaran Pada Matakuliah Trigonometri. Jurnal Pendidikan Dan Kebudayaan, 9(1).

Situmorang dkk. (2015). Penerapan Model Pembelajaran Problem Based Learning Untuk Meningkatkan Hasil Belajar Siswa Pada Materi Sistem Ekresi Manusia. Jurnal EduBio Tropika, 3(2).

Subekti, F. E. (2014). Pengembangan Perangkat Pembelajaran Matematika Kelas X SMK dengan Model Problem Solving Heuristic Berprinsip Pengelolaan Laboratorium Teenzania. Euclid, 1(2). 
Kartu untuk Meningkatkan Kemampuan Pemahaman Konsep Mataematis Siswa SMP, Fidi Dwi Anita, Pujia Siti Balkist, Novi Andri Nurcahyono

Sugiyono. (2015). Metode Penelitian \& Pengembangan Research And Development. Bandung: Alfabeta.

Supriatna, A., \& Nurcahyono, N. A. (2017). Etnomatematika: Pembelajaran Matematika Berdasarkan Tahapan-tahapan Kegiatan Bercocok Tanam. Seminar Nasional Pendidikan.

Tri, W., \& Hidayati, N. (2019). Analisis Kemampuan Pemahaman Matematis Siswa Kelas VIII SMP Negeri Karawang Barat dalam Menyelesaikan Soal Cerita dengan Materi Aritmatika Sosial. Sesiomadika.

Witantyo, M. (2017). Pengembangan Media Pembelajaran Kartu Uno Akuntansi Untuk Meningkatkan Motivasi Belajar Siswa Kelas X Akuntansi 4 SMK YPKK 2 Sleman Tahun Ajaran 2016/2017. UNY. 